\title{
Wall Structure of the Sporonts of Encephalitozoon cuniculi Grown in Human Fibroblasts
}

\author{
By R. C. HAMILTON, J. C. COX AND D. PYE \\ Commonwealth Serum Laboratories, Parkville, Victoria 3052, Australia
}

(Received 29 July 1976)

INTRODUCTION

Encephalitozoon (Nosema) cuniculi is a protozoan parasite (Microsporida, Nosematidae) which produces chronic, often latent, infections in laboratory animals, especially rabbits. These infections may seriously affect the interpretation of experimental results. Although there have been several reports on the ultrastructure of Encephalitozoon cuniculi growing in a variety of cell types, there has been some confusion about the exact nature of the limiting layers of the sporont. Lainson et al. (1964) in describing the developmental cycle of E. cuniculi stated that the sporonts secreted a thick capsule. Petri \& Schiødt (1966) published electron micrographs of sporonts but thought that they were 'parts of the host cell cytoplasm' even though they were 'limited by an external membrane which is considerably thicker than the plasma membrane'. Although his material was not well preserved, Akao (1969, Fig. 14) showed an early sporont with a discontinuous cell wall. Petri (I969) described a stage in which 'the surface (unit membrane) is covered by an electron dense layer with a number of fenestrations'. Sprague \& Vernick (197I) described cells on the periphery of the parasitophorous vacuole which began 'to develop thick membranes', and they regarded these as sporonts. According to Pakes, Shadduck \& Cali (1975) sporogony started when the organisms became detached from the vacuolar membrane and the single limiting membrane thickened.

To provide antigen for an immunofluorescence test for encephalitozoonosis (Cox \& Pye, 1975), E. cuniculi was grown to high titre in CSL 300 cells, a human fibroblast-like cell line derived from foetal tongue. We have studied the growth cycle of $E$. cuniculi in these cells and have observed, in detail, the development of the limiting layers of the sporont.

\section{METHODS}

Encephalitozoon cuniculi was grown to high titre in CSL 300 cells according to the method used by Cox \& Pye (1975) for the routine production of antigen for an immunofluorescence test. The infected cells were detached from the glass by trypsin/versene and pelleted by centrifuging. The pellet of cells was fixed in a mixture of $2 \%(\mathrm{w} / \mathrm{v})$ formaldehyde and $2.5 \%(\mathrm{v} / \mathrm{v})$ glutaraldehyde in $0 . \mathrm{I} \mathrm{M}$-cacodylate buffer $\mathrm{pH} 7.2$ containing $2.5 \mathrm{~mm}-\mathrm{CaCl}_{2}$, for $4 \mathrm{~h}$ at room temperature. The fixed pellet was minced into small blocks which were washed for $2 \mathrm{~h}$ in several changes of $\mathrm{O} \cdot \mathrm{I} \mathrm{M}$-cacodylate buffer $\mathrm{pH} 7 \cdot 2$ and then postfixed in $\mathrm{I} \%(\mathrm{w} / \mathrm{v})$ osmium tetroxide in the same buffer for $\mathrm{I} h$ at $0{ }^{\circ} \mathrm{C}$. The blocks were dehydrated in an ascending acetone series and embedded in Durcupan ACM (Fluka, Buchs, Switzerland). Sections were cut on an LKB Ultratome III, stained with lead citrate for $5 \mathrm{~min}$ at room temperature, and examined with a Philips EM 30I electron microscope. 

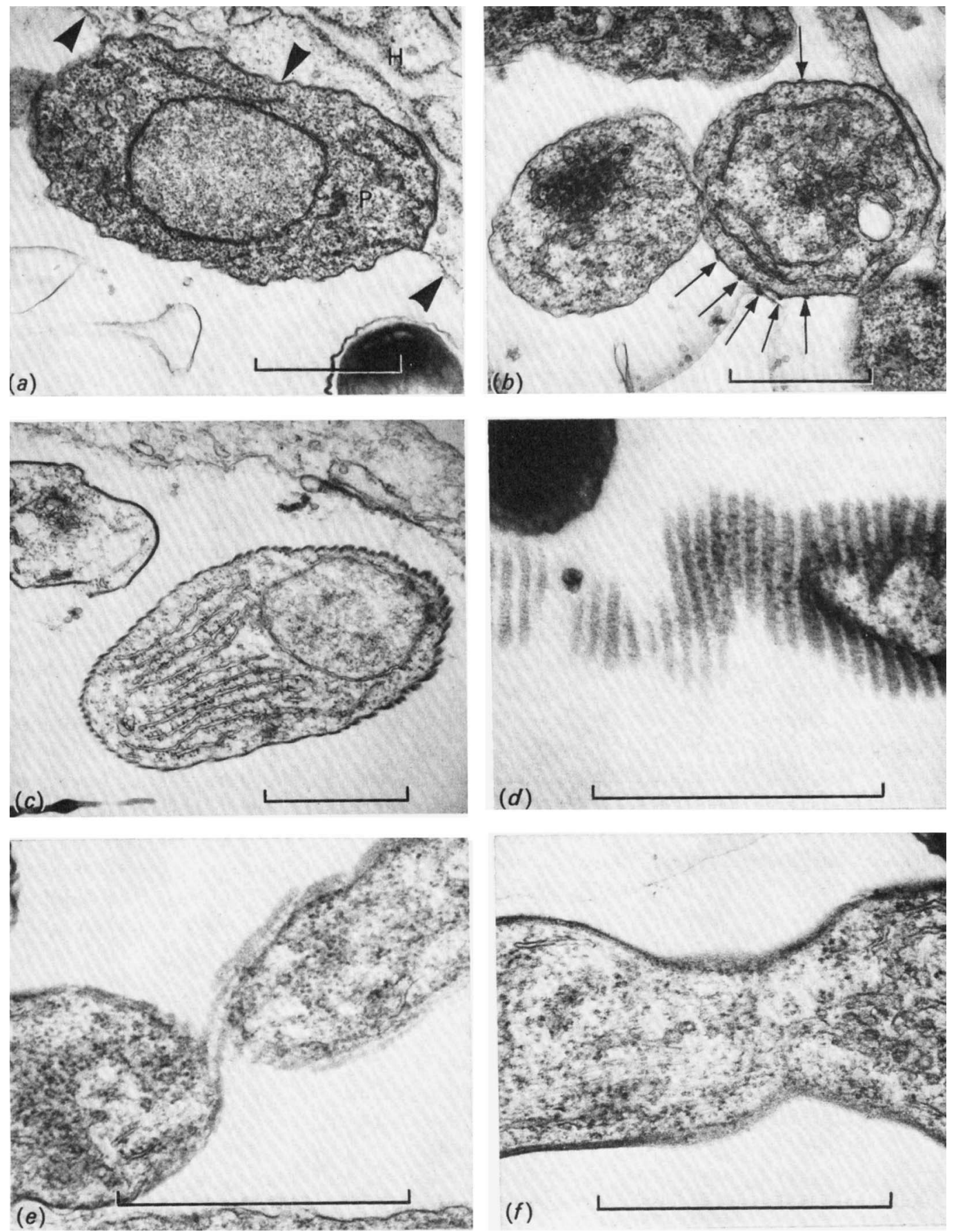

Fig. I. Electron micrographs of sections of Encephalitozoon cuniculi. (a) Proliferative form(P) closely attached to the host cytoplasm $(\mathrm{H})$; arrows show host membranes. (b) Early sporont; arrows show threads of wall. $(c)$ Sporont surrounded by threads of wall material, transverse section. (d) Sporont surrounded by threads of wall material, tangential section. (e) Sporont, with threads of wall, dividing to form sporoblasts. $(f)$ Sporont, with complete wall, dividing to form sporoblasts. Bar markers represent $\mathrm{I} \mu \mathrm{m}$. 


\section{RESULTS AND DISCUSSION}

The proliferative forms of $E$. cuniculi growing in CSL 300 cells occurred within a parasitophorous vacuole. They were in close contact with the membrane of the vacuole and were sometimes deeply indented into the host cytoplasm (Fig. I $a$ ). This is essentially as has been described for $E$. cuniculi growing in other cell types. The proliferative forms were limited by a single unit membrane. The sporoblasts of E. cuniculi occurred unattached within the parasitophorous vacuole and were surrounded by both a unit membrane and a wall.

The first appearance of the wall was a series of threads of material on the vacuolar side of the proliferative form (Fig. I $b$ ). Presumably this material was secreted by the organism. After the organism had become detached from the host membrane, the threads of material were apparent on all sides of the sporont (Fig. I $c$ ). More threads appeared until virtually the whole of the sporont was covered by threads of material. The thread-like nature of the material was particularly obvious in early sporonts that were sectioned in a plane tangential to the surface (Fig. I $d$ ). The threads thickened across the surface of the organism until the sporont was covered by an electron-dense layer with a number of fenestrations. The process continued until the mature sporont was completely surrounded by a wall (Fig. If).

The timing of these events was somewhat variable. However, there were no threads of wall material between an organism and its host membrane before it detached from the vacuolar membrane into the parasitophorous vacuole. Most detached organisms had some threads of material around them. The sporonts were capable of dividing into sporoblasts whether they were covered only by threads of material (Fig. I $e$ ) or completely enveloped by a wall (Fig. I $f$ ).

These observations extend our knowledge of the ultrastructure of E. cuniculi. They indicate that the sporont of E. cuniculi is limited by both a unit membrane and a wall, and not by a thickened membrane as suggested by Sprague \& Vernick (1971) and Pakes et al. (1975). They also indicate that the wall is secreted by the sporont (Lainson et al., 1964) as a series of threads which increase in number and size until the sporont is completely enveloped by a wall.

We thank R. J. Sikkes for his excellent technical assistance.

\section{REFERENCES}

AKaO, S. (1969). Studies on the ultrastructure of Nosema cuniculi a microsporidian parasite of rodents. Japanese Journal of Parasitology 18, 8-20.

Cox, J. C. \& PYE, D. (I975). Serodiagnosis of nosematosis by immunofluorescence using cell-culture-grown organisms. Laboratory Animals 9, 297-304.

Lainson, R., Garnham, P. C. C., Killick-Kendrick, R. \& Bird, R. G. (1964). Nosematosis, a microsporidial infection of rodents and other animals, including man. British Medical Journal 2, 470-472.

Pakes, S. P., Shadduck, J. A. \& Cali, A. (1975). Fine structure of Encephalitozoon cuniculi from rabbits, mice and hamsters. Journal of Protozoology 22, 48I-488.

Petri, M. (1969). Studies on Nosema cuniculi found in transplantable ascites tumours with a survey of microsporidiasis in mammals. Acta pathologica et microbiologica scandinavica. Suppl. 204.

Petri, M. \& SChIøDT, T. (I966). On the ultrastructure of Nosema cuniculi in the cells of Yoshida rat ascites sarcoma. Acta pathologica et microbiologica scandinavica 66, 437-446.

Sprague, V. \& Vernick, S. H. (I971). The ultrastructure of Encephalitozoon cuniculi (Microsporida, Nosematidae) and its taxonomic significance. Journal of Protozoology 18, 560-569. 